McGill Law Journal

Revue de droit de McGill

\title{
Pleasure Reading
}

Ummni Khan, Vicarious Kinks: S/M in the Socio-Legal

Imaginary (Toronto: University of Toronto Press, 2014), pp 376. ISBN 978-1-4426-1551-9

\section{Dana Phillips}

Volume 61, numéro 1, september 2015

URI : https://id.erudit.org/iderudit/1035389ar

DOI : https://doi.org/10.7202/1035389ar

Aller au sommaire du numéro

Éditeur(s)

McGill Law Journal / Revue de droit de McGill

ISSN

0024-9041 (imprimé)

1920-6356 (numérique)

Découvrir la revue

Citer ce compte rendu

Phillips, D. (2015). Compte rendu de [Pleasure Reading / Ummni Khan, Vicarious Kinks: S/M in the Socio-Legal Imaginary (Toronto: University of Toronto Press, 2014), pp 376. ISBN 978-1-4426-1551-9]. McGill Law Journal / Revue de droit de McGill, 61(1), 221-230. https://doi.org/10.7202/1035389ar d'utilisation que vous pouvez consulter en ligne. 
McGill Law Journal — Revue de droit de McGill

\section{PLEASURE READING-}

A Review of Ummni Khan, Vicarious Kinks: $\boldsymbol{S} / \boldsymbol{M}$ in the Socio-Legal

Imaginary (Toronto: University of Toronto Press, 2014), pp 376.

ISBN 978-1-4426-1551-9

\section{Dana Phillips*}

\section{Introduction}

To write a book in support of sadomasochism $(\mathrm{s} / \mathrm{m})$ is a risky undertaking for a legal academic. To succeed, she must establish scholarly credibility for a cause that has been either ignored or treated with suspicion by most of her colleagues, all the while staying true to the prioritization of sensual pleasure at s/m's heart. Canadian law and sexuality scholar Ummni Khan rises brilliantly to the challenge in her recently released monograph, Vicarious Kinks: S/M in the Socio-Legal Imaginary. ${ }^{1}$

Khan does not provide easy answers about how we ought to understand, or legally regulate, $\mathrm{s} / \mathrm{m}$. Instead, she examines, in her first three chapters, how the meaning of $\mathrm{s} / \mathrm{m}$ is constructed by three intersecting social discourses: the psychiatric definitions of the American Diagnostic and Statistical Manual of Mental Disorders (DSM), and other medical discourse; the political claims of the feminist sex wars; and the cultural representations of film. The final two chapters of the book look at how these discursive constructions play into the judicial treatment of $\mathrm{s} / \mathrm{m}$ pornography and practice in Canada and abroad. Khan skillfully weaves together

* LLM and PhD Candidate, Osgoode Hall Law School. JD, University of Victoria, Faculty of Law. Thank you to Professors Dayna Scott and Susan Drummond for running the workshop that kick-started this project, and for offering feedback and encouragement. I am grateful to Professor Benjamin Berger for his helpful comments on the first draft, and for his support and guidance in seeking publication. I also wish to thank my anonymous peer reviewer for a thought-provoking assessment of the piece, as well as the editorial board of the McGill Law Journal for its diligent engagement with the text throughout the editing process. Finally, I wish to note that it was my pleasure to work briefly with the author as a research assistant for a different project, and to perform a piece of spoken word poetry at the launch of this book.

(C) Dana Phillips 2015

Citation: (2015) 61:1 McGill LJ 221 — Référence : (2015) 61:1 RD McGill 221

1 Ummni Khan, Vicarious Kinks: S/M in the Socio-Legal Imaginary (Toronto: University of Toronto Press, 2014). 
her analysis of each discursive framework to paint a rich picture of the stories we tell about $\mathrm{s} / \mathrm{m}$, and how those stories influence the legal interests of its practitioners.

\section{Theoretical Framework}

To advance her argument, Khan deploys a robust theoretical framework. The centrepiece is Michel Foucault's theory of how knowledge and power work to produce pleasure, an insight that plays out with respect to $\mathrm{s} / \mathrm{m}$ in at least two ways. In one sense, the condemnation of $\mathrm{s} / \mathrm{m}$ within dominant social discourses has the side effect of heightening its illicit allure. While this theme reappears throughout Vicarious Kinks, even more central to the book is Foucault's claim that the pursuit of "objective" truth, including the truth about sexuality, is pleasurable in itself. ${ }^{2}$ Applying this idea to the $\mathrm{s} / \mathrm{m}$ context, Khan argues that the attempts of psychiatry, feminism, and film to pin down the truth about $\mathrm{s} / \mathrm{m}$ actually serve as an "incitement to discourse", ${ }^{3}$ amplifying the phenomenon of $\mathrm{s} / \mathrm{m}$ in social consciousness even while warning of its dangers, and taking pleasure in the voyeuristic assessment of $\mathrm{s} / \mathrm{m}$ representations and practices, even while denying the pleasures of $\mathrm{s} / \mathrm{m}$ practitioners themselves.

Theories of abjection and disgust provide a secondary grounding for Khan's work. According to her, s/m finds pleasure in the "abject"unstable spaces where categories of identity, meaning, and social ordering break down. In opposition, anti-s/m discourses invoke disgust as a strategy to police and thereby reinforce the boundaries of sexual normativity. ${ }^{4}$ However, as Khan notes, the denigration of $\mathrm{s} / \mathrm{m}$ through the rhetoric of disgust also serves as a "device[] of excitation and incitement," offering vicarious pleasures to those who stand in judgment. ${ }^{5}$ In other words, even those who speak out most vehemently against $\mathrm{s} / \mathrm{m}$ get off on doing so. At the same time, efforts to stamp out $\mathrm{s} / \mathrm{m}$ sexuality contribute to the abject status of its practitioners, allowing them to "revel in their outlaw status" and producing new fodder for $\mathrm{s} / \mathrm{m}$ fantasies. ${ }^{6}$

2 Michel Foucault, The History of Sexuality (Toronto: Vintage Books, 1990) vol 1 at 71, cited in Khan, supra note 1 at 17.

3 Khan, supra note 1 at 71.

4 See ibid at $17-18$.

5 Khan, supra note 1 at 19, citing Foucault, supra note 2 at 48.

6 Khan, supra note 1 at 154. 


\section{Khan's Situated Epistemology}

One of the most striking aspects of Vicarious Kinks is Khan's unfailing self-reflexivity. As she acknowledges at the outset, her book is itself a source of "vicarious kink" - -we all want to read it, even if only to dismiss, or actively condemn, the argument it advances. Regardless of whether you agree with her stance on $\mathrm{s} / \mathrm{m}$, Khan's steadfast commitment to situating herself as a researcher and author is commendable. Moreover, the risks she takes in doing so create a sense of intimacy and trust with the reader. The autobiographical screenplay that opens the book is a case in point; we first meet Khan not as an objective academic narrator, but as a conflicted university student grappling with her "own private sex wars." (We also meet her as a somewhat cheesy creative writer.) The dramatic genre underscores the book's engagement with law and film, and appeals to the reader at a visceral level. As Khan readily admits in the opening lines of her introduction, she hopes that the screenplay "will have a seductive effect on the reader." 9 This aspiration resonates with the validation of carnal responses and desires in other pro-s/m works that Khan discusses, drawing upon what she refers to as the "corporeal epistemology" of pro$\mathrm{s} / \mathrm{m}$ politics. ${ }^{10}$

Khan's personal reveal about the evolution of her own thinking and experience with respect to $\mathrm{s} / \mathrm{m}$ piques a gut curiosity, inviting the reader to take a similar intellectual (and perhaps also sexual) journey. In a clever segue into the book, she goes on to use her creative storytelling as an illustration of how narrative constructions are inherently value-laden (in her case "romanticiz[ing] sexual alterity")—a lesson to be applied to social constructions of $\mathrm{s} / \mathrm{m} .{ }^{11}$ However, her most telling comments about the screenplay appear later on, when she explains it as a response to her struggle to situate herself as both an unbiased researcher and a credible insider to $\mathrm{s} / \mathrm{m}$ culture ${ }^{12}$ - $\mathrm{a}$ theme that pervades the entire book.

On the one hand, Khan casts doubt on the purported objectivity of mainstream scientific claims about $\mathrm{s} / \mathrm{m}$, such as those advanced by the provisions of the DSM (Chapter 1) and the expert evidence of a number of health professionals in s/m-related cases (Chapter 5). Instead of supporting such attempts at clinical detachment, she champions the blurring of

Ibid at 13.

$8 \quad$ Ibid at 3.

9 Ibid at 10.

$10 \quad$ Ibid at 94 .

11 Ibid at 10.

12 Ibid at 279-80. 
distance between researcher or "expert" and object of study as a consciously political epistemology. For example, in her discussion of pro-s/m research that challenges the "pathologizing gaze" of psychiatry (as reflected in the $D S M),{ }^{13}$ Khan praises the work of Staci Newmahr, who chronicles her own participation in the $\mathrm{s} / \mathrm{m}$ activities of a community in England. For Khan, Newmahr's personal involvement "radically breaks down the binary between scientific observer and $\mathrm{s} / \mathrm{m}$ participants as objects of knowledge, and thus continues the project of destigmatization."14

On the other hand, Khan seems eager to shore up her academic credibility by offering a fair and comprehensive account of her subject. For instance, while she begins her chapter on feminism by frankly stating, "I offer no pretensions of neutrality" (she is on the side of the sex-radicals), she hastens to assure her reader: "That being said, however, I endeavour to interrogate the truth-claims about $\mathrm{s} / \mathrm{m}$ that were put forth from every side of the debate." 15 Moreover, while Khan rejects claims to scientific objectivity, this seems incongruent with some of her own arguments. Khan herself frequently points to empirical evidence (or a lack thereof) as a way to challenge mischaracterizations of $\mathrm{s} / \mathrm{m}$, thereby affirming an objective standard of truth on the matter. ${ }^{16}$ At one point, she even laments that the Provincial Court of British Columbia, in the 2006 case of R. v. R.D.W., ${ }^{17}$ did not consult the $D S M$ or any medical experts to help determine when $\mathrm{s} / \mathrm{m}$ behaviour becomes pathological (the court in that case simply assumed that $\mathrm{s} / \mathrm{m}$ activities were unhealthy). ${ }^{18}$ Khan also appears anxious to back her own claims empirically, going so far as to use the work of Charles Darwin to support her interpretation of one of Vince Vaughn's facial expressions in the film Wedding Crashers. ${ }^{19}$

The problem is that the entire thrust of Khan's project seeks to deconstruct "objective" knowledge claims about $\mathrm{s} / \mathrm{m}$, including her own. This goal, however, sits in tension with Khan's pro-s/m politics, which cannot be advanced without some non-relativistic claim to truth. Khan's principled answer to this dilemma is to privilege marginalized and "insider"

See e.g. ibid at 51 (citing a that $\mathrm{s} / \mathrm{m}$ causes personal distress or dysfunction); ibid at 199-200 (noting how the Supreme Court of Canada in $R v$ Butler ignores social science evidence that shows no link between pornography and violent crime); ibid at 245 (noting how a Manitoba court implied that $\mathrm{s} / \mathrm{m}$ leads to sexually violent tendencies without any empirical evidence).

Khan, supra note 1 at 252.

Ibid at 126. 
perspectives, particularly those of $\mathrm{s} / \mathrm{m}$ practitioners themselves. She seeks to challenge the fact that, "[f]rom the law's perspective, sadomasochists are not proper cartographers of their own desires." ${ }^{20}$ Thus, while she is careful to acknowledge that all narratives invoke a normative agenda, she tends to challenge those that reflect dominant, negative understandings of $\mathrm{s} / \mathrm{m}$ culture, and tends to validate those that present alternative perspectives or speak from lived experience (or both). For instance, after canvassing the anti-s/m norms operating within mainstream psychiatric discourse, Khan goes on to cite with approval the work of Charles Moser and Peggy Kleinplatz, two pro-s/m health professionals who conclude that the pathologization of $\mathrm{s} / \mathrm{m}$ has no basis in evidence. ${ }^{21}$ Even here, however, Khan acknowledges that "this stance, of course, attaches truth to rationality, objectivity, and empiricism," 22 once again demonstrating her acute awareness of the normative values underpinning her own arguments. She justifies the pro-s/m scientific research, however, as an effective "counterhegemonic strategy" that challenges the mainstream psychiatric discourse "on its own terms." 23

Khan is remarkably self-critical, but she does not always adhere perfectly to her epistemological principles. Despite emphasizing the need to listen to the voices of $\mathrm{s} / \mathrm{m}$ participants themselves, and to women in particular, at times she can be uncharitable to experiential accounts that do not reflect her own politics. For instance, in her discussion of anti-s/m feminist discourse, she strongly criticizes the narratives of two women, Marissa Jonel and Elizabeth Harris, who describe negative personal experiences with $\mathrm{s} / \mathrm{m}$, accusing them of perpetuating notions of $\mathrm{s} / \mathrm{m}$ as violent, addictive, and dysfunctional. ${ }^{24}$ It is ironic, given her general validation of first hand sexual knowledge, that she dismisses Jonel's account as mere "anecdotal experience." 25

22 Ruth Linden et al, eds, Against Sadomasochism: A Radical Feminist Analysis (San Francisco: Frog in the Well, 1982) 16 and Elizabeth Harris, "Sadomasochism: A Personal Experience" in Linden et al, supra note 24, 93. Khan, supra note 1 at 153 .

Ibid at 217.

Ibid at 51, citing Peggy J Kleinplatz \& Charles Moser, "Is SM Pathological?" (2005) 6:3 Lesbian and Gay Psychology Rev 255.

Khan, supra note 1 at 52.

Ibid.

Ibid at 73-76 responding to Marissa Jonel, "Letter From a Former Masochist" in Robin$$
\text { Khan, supra note } 1 \text { at } 153 .
$$ 


\section{Dominant Portrayals of $\mathrm{S} / \mathrm{M}$}

Despite Khan's occasional lack of charity to those with whom she disagrees, Vicarious Kinks remains impressively balanced, offering a thorough and nuanced mapping of the dominant cultural messages about $\mathrm{s} / \mathrm{m}$ and how they are reiterated and resisted within various forms of social discourse. Khan also illustrates how representations and interpretations of $\mathrm{s} / \mathrm{m}$ reinforce stereotypes of gender, race, class, and sexual orientation. Not surprisingly, the political, cultural, and legal denigration of $\mathrm{s} / \mathrm{m}$ is particularly acute where the activities at issue subvert other norms of gender and sexuality, such as through the involvement of male submissives, female dominants, or LGBT-identified participants. Of particular interest is the link that Khan illuminates between the criminalization of s/m and sex work. ${ }^{26}$ Given her observation that sex work has taken the spotlight in recent feminist scholarship, ${ }^{27}$ this connection points to the broader implications of her work.

Within her rich analysis, Khan underscores two particularly problematic elements in feminist and legal interpretations of $\mathrm{s} / \mathrm{m}$ : (1) the misinterpretation of $\mathrm{s} / \mathrm{m}$ scenes as literal imitations of real world hierarchies; and (2) the failure to recognize the salience of consent in $\mathrm{s} / \mathrm{m}$ encounters. Her discussion of the factum submitted by feminist intervenor organization LEAF in the obscenity case $R$. $v$. Butler ${ }^{28}$ illustrates the first critique. ${ }^{29} \mathrm{In}$ opposition to the literalist understandings of $\mathrm{s} / \mathrm{m}$ advanced by LEAF and accepted by the court, Khan describes $\mathrm{s} / \mathrm{m}$ as a reappropriating practice, one that "perverts hierarchy, takes advantage of hierarchy's sexual residue, and prioritizes pleasure at the expense of order and coherence." ${ }^{30}$ She goes on to note the irony by which "legal hierarchy [the criminal law] is called in to protect the sanctity of social hierarchy and to disavow its sexual leakages." 31

Khan also highlights how anti-s/m discourses tend to blur the distinction between consensual $\mathrm{s} / \mathrm{m}$ and sadistic violence. For example, she notes

See e.g. ibid at 100 (noting the historical criminalization of $\mathrm{s} / \mathrm{m}$ under anti-prostitution laws); ibid at 154 (discussing the conceptual link drawn between the criminality/immorality of prostitution and $\mathrm{s} / \mathrm{m}$ in the film Nine and a Half Weeks); ibid at 270-71 (discussing the criminalization of a professional dominatrix under anti-prostitution laws in $R v$ Bedford (2000), 184 DLR (4th) 727, 143 CCC (3d) 311 (Ont CA) [Bedford Ont CA]; $R$ v Bedford, [1998] OJ No 4033 (QL) (Ont Ct J) [Bedford Ont Ct J]).

Khan, supra note 1 at 115 .

Ibid at 187.

Ibid. 
a recurring theme within psychiatry, radical feminism, film, and jurisprudence that masochists are inherently self-destructive, helpless victims whose purported enjoyment of submissive sexuality reflects mental and emotional instability rather than genuine sexual agency. Sadists on the other hand, are widely portrayed as violent and aggressive abusers with no concern for the pleasure or well-being of their masochist "victims". These discourses, most notably feminist and legal discourses, often fail to ascribe significance to the presence of clear and informed consent in $\mathrm{s} / \mathrm{m}$ scenarios-an important line that separates them from situations of sexual violence. Although the law purportedly values consent, consent does not redeem activities that violate other norms of gender and sexuality, and indeed may be damning in such circumstances. In Butler, for instance, the Court finds that consent cannot exculpate material that has already been found to be "degrading or dehumanizing", and may even make it worse. ${ }^{32}$ In the notorious British $\mathrm{s} / \mathrm{m}$ case of $R$. v. Brown,,$^{33}$ the House of Lords finds that the law will tolerate "rough horseplay" as part of male social life, but not explicitly consensual gay s/m. ${ }^{34}$ As Khan astutely observes, the provision of negotiated and informed consent is precisely what makes gay s/m unmanly, separating it from "normal" (i.e., violent) male physical aggression..$^{35}$

While Khan places rightful emphasis on consent as an overlooked or improperly weighted factor in normative evaluations of $\mathrm{s} / \mathrm{m}$, her analysis would be enriched by a deeper engagement with the extensive feminist literature that has critiqued consent as a complex and problematic standard. ${ }^{36}$ Khan does not define her understanding of consent, or explain why

Butler, supra note 28 at 479, cited in Khan, supra note 1 at 197.

[1994] 1 AC 212, [1993] 2 All ER 75 (HL).

Khan, supra note 1 at 232.

Ibid at 232-33.

See e.g. Lise Gottel, "Governing Heterosexuality Through Specific Consent: Interrogating the Governmental Effects of $R v J A$ " (2012) 24:2 CJWL 359 (critiquing the individualized and decontextualized framing of consent in a recent Supreme Court of Canada case); Deborah Tuerkheimer, "Sex Without Consent" (2013) 123 Yale LJ Online 335, online: <www.yalelawjournal.org/forum/sex-without-consent> (arguing for a concept of "agency" that recognizes both sexual self-direction and social constraints on sexual choice as the touchstone value of American rape law); Robin West, "Sex, Law, and Consent" in Franklin Miller \& Alan Wertheimer, eds, The Ethics of Consent: Theory and Practice (Oxford: Oxford University Press, 2009) 221 (arguing that the liberal legal focus on consent legitimizes the harms that may arise from consensual sex); Kathryn Abrams, "From Autonomy to Agency: Feminist Perspectives on Self-Direction" (1999) 40:3 Wm \& Mary L Rev 805 (considering how feminist theory has modified traditional liberal notions of autonomy); Catharine A MacKinnon, Toward a Feminist Theory of the State (Cambridge, Mass: Harvard University Press, 1989) (questioning the meaning of consent in a male-dominated society); Carole Pateman, "Women and Consent" (1980) 
she positions it as such a central sexual value, which seems like somewhat of an oversight given the rich body of scholarship on this issue. She does, however, acknowledge that there may be good policy reasons to be skeptical of alleged consent to $\mathrm{s} / \mathrm{m}$ in sexual assault cases. ${ }^{37}$ She also addresses feminist concerns about structural constraints on agency in her discussion of $R$. v. J.A., ${ }^{38}$ a sexual assault case involving a relationship marked by both $\mathrm{s} / \mathrm{m}$ and domestic violence. Khan advocates a view of the recanting complainant in J.A. as "someone who negotiates both pleasure and danger in her relationship," 39 thereby presenting a more nuanced understanding of consent that still privileges sexual agency and $\mathrm{s} / \mathrm{m}$ pleasure.

\section{Resistant Discourses, Social Justice, and the Celebration of S/M}

In addition to demonstrating the pervasiveness of anti-s/m sentiment and the power of gender norms within mainstream discourses, Khan pulls out examples of works and decisions that go against the grain of dominant stereotypes. These include: the challenges raised to the medical pathologization of $\mathrm{s} / \mathrm{m}$ by Moser and Kleinplatz; ${ }^{40}$ the "resistance discourse" of pro$\mathrm{s} / \mathrm{m}$ authors and activists such as Gayle Rubin and Patrick Califia; ${ }^{41}$ the nuanced portrayal of a budding female dominatrix in the 2007 indie film Walk All Over Me; ${ }^{42}$ and Ontario Justice Wolder's context-sensitive assessment of an intergenerational $\mathrm{s} / \mathrm{m}$ relationship in the 2011 criminal case of $R$. v. M.(P.). ${ }^{43}$ In response to the plethora of anti-s/m views she encounters, Khan draws upon these and other moments of resistance to challenge common misconceptions and portray $\mathrm{s} / \mathrm{m}$ sexuality in a more positive light.

Indeed, the normative undercurrent of Vicarious Kinks celebrates s/m as a site of pleasure, empowerment, and resistance against sexual hegemony. At the same time, Khan offers a compelling portrayal of $\mathrm{s} / \mathrm{m}$ as a social justice issue. Here is where her disciplined and nuanced theoretical analysis links up with her politics. Khan persuasively argues that denigrating social narratives about $\mathrm{s} / \mathrm{m}$ carry significant material consequenc-

8:2 Political Theory 149 (tying a critique of political consent theory to how consent operates in women's everyday lives).

Khan, supra note 1 at 249.

2011 SCC 28, [2011] 2 SCR 440.

Khan, supra note 1 at 267.

Ibid at 50-52.

Ibid at 92 .

Ibid at $150-51$.

2011 ONCJ 401, 2011 CarswellOnt 8292, cited in Khan, supra note 1 at 288-90. 
es for practitioners. The most striking evidence for this appears in the last chapter of the book, which addresses the law's treatment of $\mathrm{s} / \mathrm{m}$ practice. Here we learn how those who transgress norms of gender and sexuality through $\mathrm{s} / \mathrm{m}$ have been subjected to lengthy imprisonment $(R . v$. Brown, $R$. v. J.A.), abusive and degrading treatment by the police (R. $v$. Bedfor $d^{44}$ ), loss of parental rights (Smith $v$. Smith ${ }^{45}$ ), psychological or psychiatric interventions (R. v. R.D.W., Smith v. Smith) and, of course, social stigmatization (R. v. J.A., Mosley v. News Group Newspapers Limited,46 the Corporal James Charles Brown lawsuit 47 ). As Khan compellingly observes: "The cruel irony then is that the dominant script in the socio-legal imaginary casts $\mathrm{s} / \mathrm{m}$ as violent, while the violence imposed by the law upon the bodies and subjectivities of $\mathrm{s} / \mathrm{m}$ practitioners happens offstage, outside of the narrative." 48

While Khan advocates for greater understanding and acceptance of $\mathrm{s} / \mathrm{m}$, she is not blind to the costs of normalization. As she demonstrates in her analysis of a number of films including the popular 2002 film Secretary, as well as in her discussion of the popular literary trilogy Fifty Shades of Grey, positive portrayals of s/m sexuality often purchase mainstream credibility through adherence to other privileged social forms, such as monogamy, heterosexuality, whiteness, and physical attractiveness. And, while some $\mathrm{s} / \mathrm{m}$ practitioners have started using the law to seek positive recognition of their sexual identities in ways that Khan views as both promising and inspiring, she also notes that "the cost of casting oneself as a liberal legal subject can be to reify identity, uphold the sexual chauvinism of the status quo, and displace abjection onto other, more marginalized subjects." ${ }^{4}$ Indeed, these are the same issues that arise with increasing social and legal acceptance of almost any previously marginalized group. Although not discussed in the book, another potential cost more particular to $\mathrm{s} / \mathrm{m}$ begs consideration: as a form of sexuality that derives pleasure from abjection, taboo, and the re-appropriation of social hegemonies, does the erotic power of s/m depend on its illicit status?

44 Bedford Ont CA, supra note 26; Bedford Ont Ct J, supra note 26.

45 This American case was discussed in Marty Klein \& Charles Moser, "S/M (Sadomasochistic) Interests as an Issue in a Child Custody Proceeding" (2006) 50:2\&3 J Homosexuality 233. Klein and Moser anonymized the parties to protect their identities, noting only that the case was published in 2003.

46 [2008] EWHC 1777, 2008 WL 2872466 (Westlaw) (QB).

47 This is an ongoing lawsuit. RCMP Corporal Brown launched a civil lawsuit in 2012 alleging defamation and breach of privacy after he was exposed and castigated in the media for s/m-themed photos that he allegedly posted on the kink site "Fetlife". See Brown $v$ Ward (1 November 2012), Vancouver S-127697 (BC Sup Ct). 
It would be easy for an academic project as rigorously intellectual as Khan's to inadvertently kill the visceral eroticism that makes $\mathrm{s} / \mathrm{m}$ worth celebrating in the first place. However, Khan's unorthodox use of pictures, poetry, vivid descriptions of film, and of course, her own salacious screenplay, all work to create a decidedly sexy ambience, while her prose amplifies thrilling tensions in the elusive search for sexual truth. In this way, Khan manages to bring the reader back to her own body, allowing her to access the vicarious pleasures of an especially captivating story about s/m. 